\title{
Soil-Landscape Relationship in the Northern Volcanic Mountain of Leyte, Philippines
}

\author{
Roland V. Rallos ${ }^{1,2}$, Victor B. Asio ${ }^{1}$ and Faustino P. Villamayor ${ }^{1}$ \\ ${ }^{\prime}$ Department of Soil Science, Visayas State University, Baybay City, Leyte \\ ${ }^{2}$ Philippine Nuclear Research Institute, Diliman, Quezon City
}

\section{ABSTRACT}

Studies on soil-landscape relationships are necessary to improve our understanding of the spatial distribution and variation of soils for their sustainable management. This study evaluated the relationship between soil properties and landscape position in the northern volcanic mountain of Leyte, Philippines. Five soil profiles located on summit, shoulder, backslope and footslope positions were evaluated. Findings revealed that the degree of soil development as well as the soil morphophysical and chemical properties varied with landscape position. The soil in the most stable position (summit) had thicker solum and slightly more developed soil profile than the soils in other landscape positions. On the other hand, soils in the unstable position (backslope) generally had thinner solum. All the five soils also revealed the influence of the andesitic volcanic parent material on their properties. They all showed some properties typical of Andisols such as low bulk density and high $\mathrm{pH}$ in $\mathrm{NaF}$ although they were classified as Andic Dystrudept. The soils all possessed physical and chemical constraints for crop production.

Keywords: landscape positions, fertility characteristics, volcanic soils, pedogenesis, topography, Inceptisols, Cambisols.

\section{INTRODUCTION}

Leyte was formed from geologic uplift and faulting during the time of active volcanism in the late Miocene and Quaternary period hence, andesitic, basaltic, and dacitic lava flows and pyroclastics are the dominant rocks in central Leyte (Aurelio 1992, Asio 1996, Jahn \& Asio 2006). Additionally, during the drier period of the Quaternary, the effects of climatic changes on landform development were distinctive in the Philippine archipelago and other parts of the Southeast Asian region because of the monsoonal system prevalent at the time (Verstappen 1997). Thus, the pedology of most Philippine islands including Leyte has been greatly influenced by rock types and relief characteristics.

Correspondence: V.B. Asio Address: Department of Soil Science, VSU, Baybay City, Leyte ; E-mail: vbasio@vsu.edu.ph DOI: $10.32945 /$ atr3916.2017 
Previous pedological studies in Leyte showed the dominant role of parent material, geomorphic position, and land use on the development, distribution and characteristics of the soils of the island (Asio 1996, Asio et al 1998, Zikeli et al 2000, Asio et al 2006, Navarrete et al 2008, Navarrete et al 2009, Maranguit \& Asio 2013, Asio et al 2014, Piamonte et al 2014). Similar studies in various parts of the world have also revealed that the characteristics of soils are related to their landscape positions (Schlichting 1982, Stahr 1990, Daniels \& Hammer 1992, Chen et al 1999, Sommer \& Schlichting 1997, Driessen et al 2001, Tsui et al 2004). In tropical regions specifically in Leyte, the humid condition, high average temperature and high rainfall favor rock weathering and soil development which leads to the formation and accumulation of secondary clay minerals (Mohr et al 1972, Asio 1996, Asio \& Jahn 2007, Navarrete et al 2008 \& 2009). The interplay of the soil-forming factors explains the occurrence of different soils belonging to different classification categories such as Maasin clay (southern part), Tacloban clay (northeastern part), and Guimbalaon clay (central to northern part) in Leyte island (Barrera et al 1954).

Landscape is a mixture of geophysically defined landforms that vary in size, shape, gradient and arrangement that are under the continuous influence of natural and anthropogenic events (Turner \& Gardner1991, Forman 1995). Hillslopes are classified into different landscape positions such as summit, shoulder, backslope, footslope and toeslope (Ruhe 1960 \& 1975). Pedological and hydrological processes vital for soil development often occur at varying rates along these positions (Hall 1983). Consequently, properties such as soil color and texture (Ovalles \& Collins 1986), organic matter, nitrogen (Podwojewski et al 2011), extractable phosphorus, exchangeable potassium, base saturation (Poudel \& West 1999) and overall soil fertility characteristics have been shown to vary predictably along landscape positions. Information on this relationship will help in the design of suitable soil management strategies for enhanced agricultural sustainability and land use in Leyte as well as in other regions with similar geological, pedological, and ecological conditions.

The relationship between the soils and volcanic landscapes in Leyte is still poorly understood and thus there is a need for studies focusing on this topic. Hence, this study was conducted.

\section{MATERIALS AND METHODS}

\section{Study Area}

The transect for the study extends from Kananga to Capoocan in the northern part of the Leyte cordillera at an elevation ranging from 60 to $180 \mathrm{~m}$ asl (Fig.1). The area was chosen for the study because of the 
occurrence of different soils from volcanic rocks which have not yet been studied until now. This part of Leyte is also interesting considering the existence of various land uses on the volcanic slopes.

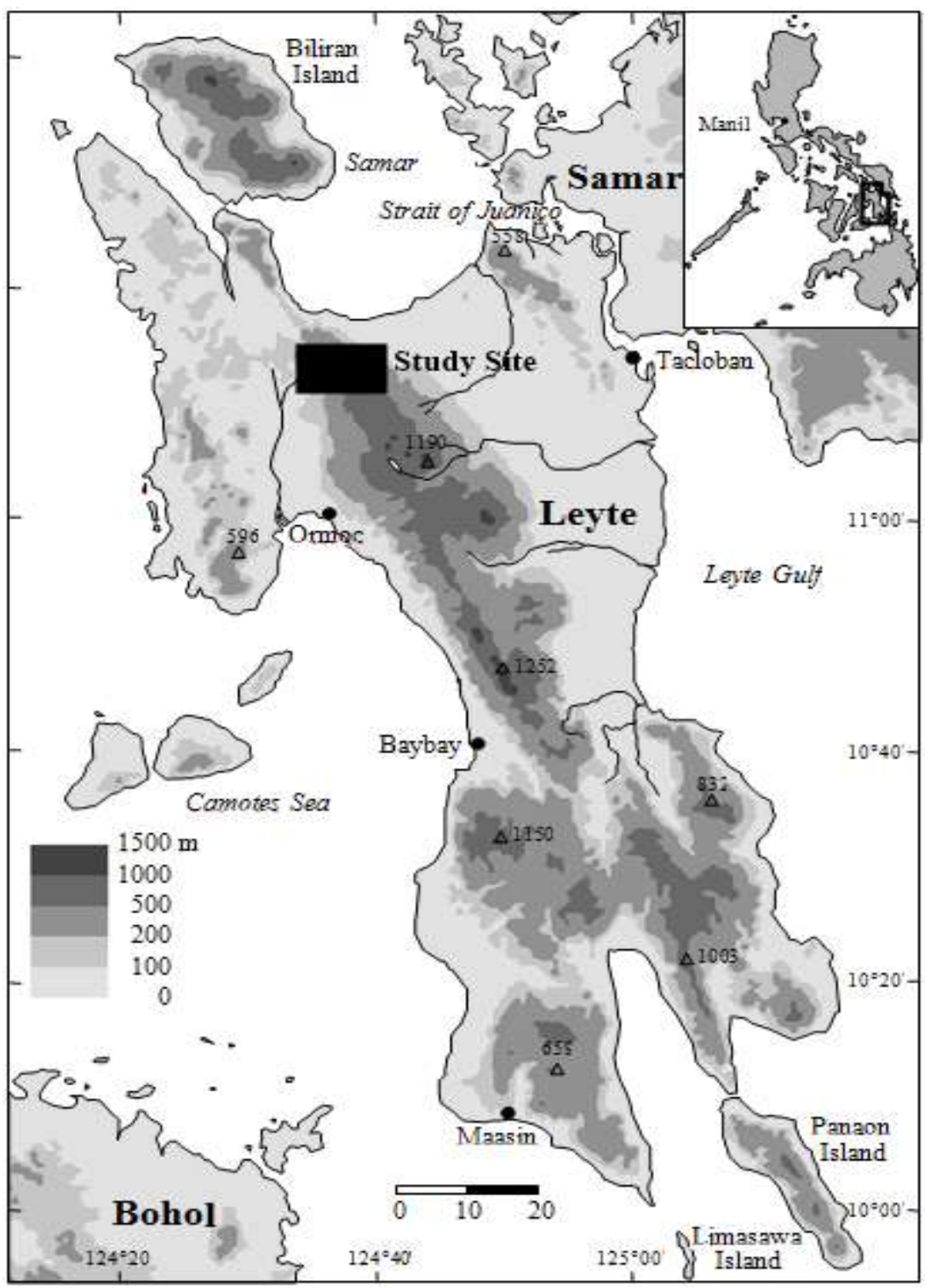

Figure 1. Location of the study area in the northern portion of the central volcanic highlands of leyte.

\section{Site Characterization}

Five sampling sites were selected described according to the FAO Guidelines for Soil Description (Jahn et al 2006). The site characteristics included location, elevation, parent material, landform, geomorphic 
position, local relief, slope gradient, slope shape, aspect, land use, predominant vegetation, and any field notes that provided information on soil properties or genesis (e.g. leaning trees as signs of soil creep).

\section{Soil Profile Description and Sampling}

Soil profiles were described and sampled on an undisturbed vertical pit face of at least $1.0 \mathrm{~m}$ deep, according to standard procedures in the FAO Guidelines for Soil Description (Jahn et al 2006). Soil samples were taken uniformly through the entire depth of each soil horizon. About one-half kg of composite soil sample was obtained from three subsamples collected quantitatively from every horizon of each soil profile according to the method of Schlichting et al (1995). Samples were air-dried, pulverized using wooden hammer, sieved to pass a 2-mm mesh, and stored in plastic containers.

Laboratory Analyses

Bulk density was determined by core method (Blake \& Hartge 1986), particle size distribution by pipette method after pretreatment of soil samples with $\mathrm{H}_{2} \mathrm{O}_{2}$ to remove organic matter (OM) (ISRIC 1995), and waterholding capacity which involves the saturation of $100 \mathrm{~g}$ of $<2 \mathrm{~mm}$ soil in perforated tin cans for 24 hours (PCARR 1980). Plant available waterholding capacity (EPAWC) was approximated based on values for texture grades (Soil Information Systems Unit 2002). Saturated hydraulic conductivity was measured using the constant head method (Amoozegar \& Warrick 1986).

Soil $\mathrm{pH}$ was determined potentiometrically using distilled water at a soil-solution ratio of 1:2.5 (ISRIC 1995). Soil $\mathrm{pH}$ in $1 \mathrm{M} \mathrm{NaF}$ was also measured following the procedure of Jara et al (2006) at a soil-solution ratio of 1:50. Organic $\mathrm{C}$ and total $\mathrm{N}$ using modified Walkley-Black and modified Kjeldhal methods, respectively (USDA-NRCS 1996). Available P was extracted using the Bray No. 2 method of Jackson (1958) and Murphy and Riley (1962) for color development and quantified by measuring the percent absorbance at $880 \mathrm{~nm}$ using Spectronic 20D ${ }^{+}$. Cation exchange capacity (CEC) was determined using $1 \mathrm{~N} \mathrm{NH}_{4} \mathrm{OAc}$ at pH 7 (USDA-NRCS 1996). Exchangeable $\mathrm{K}, \mathrm{Ca}, \mathrm{Na}$, and $\mathrm{Mg}$ were extracted using $1 \mathrm{~N} \mathrm{NH}_{4} \mathrm{OAc}$ neutralized to pH 7 (USDA-NRCS 1996) and quantified by atomic absorption spectrophotometry (AAS) (Westerman 1990). The base saturation percentage of the $\mathrm{CEC}\left(\mathrm{NH}_{4} \mathrm{OAc}\right.$ at $\mathrm{pH}$ 7.0) was calculated by dividing the total exchangeable bases with the measured CEC and the quotient was then multiplied by 100 . 
Soil Fertility Evaluation

Fertility evaluation was based on examination and analysis of the obtained morphophysical and chemical characteristics. This was achieved by matching the values of selected soil properties with published threshold/critical values for crop production (Schlichting et al 1995, Asio et al 2006). In this method, necessary information for the design of appropriate soil management strategies for the sustainable crop production can be identified (Asio et al 2006).

\section{RESULTS AND DISCUSSION}

\section{Physical Characteristics of Sampling Sites}

The physical characteristics including geomorphology of the sampling sites are presented in Table 1. Agro-climatic pattern of the study area indicates a wet climate with an annual rainfall greater than $2500 \mathrm{~mm}$, slight dry season, and a growing period of 270 - 320 days in hilly, mountainous to highland areas.

In addition, typhoons which are generally characterized by strong winds and heavy rainfall, develop several times a year (Eller \& Asio 1991, Jahn \& Asio 2006). Soil moisture and temperature regimes are udic and isohyperthermic, respectively (Soil Survey Staff 2014).

Most parts of Leyte originated from uplift, faulting, and volcanic eruption hence pyroclastics are the dominant parent materials of the soils (Aurelio 1992, Asio et al 1998, Jahn \& Asio 2006). The Philippine Fault Line which cuts the island from the north to south resulted in the chain of volcanoes that formed the Leyte cordillera. Geomorphic processes particularly weathering erosion and mass wasting modified the mountains to their present forms. Furthermore, various anthropogenic influences especially logging, shifting cultivation, perennial agriculture, and settlements have caused substantial changes in the vegetation and land cover of the island.

The five sampling sites represented different geomorphic positions but were oriented in the same northeast direction. Land uses of the sites were all perennial crops consisting of coconut, banana and with some shrubs, grasses, sedges and broadleaves thus, indicating considerable anthropogenic influence. Consequently, local inhabitants practice intensive farming triggering vegetation and soil resource degradation. The combination of heavy rainfall, high temperature and steep slope gradients further escalate the land degradation processes (e.g. erosion of the topsoil, leaching leading to infertility, high rate of weathering and extensive development of residual soils). 
Table 1. Physical characteristics and geomorphology of the soils in the northern volcanic mountain of Leyte

\begin{tabular}{|c|c|c|c|c|c|}
\hline \multirow{2}{*}{$\begin{array}{c}\text { Site } \\
\text { Characteristics }\end{array}$} & \multicolumn{5}{|c|}{ Soil Profiles } \\
\hline & 1 & 2 & 3 & 4 & 5 \\
\hline Location & Sitio Ansubas & Sitio Lauan & Brgy. Lemon & Brgy. Visares, & Brgy. Lonoy, \\
\hline Major Landform & $\begin{array}{l}\text { High gradient } \\
\text { mountain }\end{array}$ & $\begin{array}{l}\text { High gradient } \\
\text { mountain }\end{array}$ & $\begin{array}{l}\text { Medium gradient } \\
\text { mountain }\end{array}$ & plateau & Medium gradient hill \\
\hline $\mathrm{CPS}^{+}$Conrdinates & $11^{\circ} 16^{\prime} 35^{\prime \prime} \mathrm{N}$ & $11^{\circ} 15^{\prime} 10^{\prime \prime} \mathrm{N}$ & $11^{\circ} 13^{\prime} 05^{\prime \prime} \mathrm{N}$ & $11^{\circ} 10^{\prime} 50^{\prime \prime} \mathrm{N}$ & $11^{\circ} 09^{\prime} 07^{\prime \prime} \mathrm{N}$ \\
\hline GPS Coordinates & $120^{\circ} 37^{\prime} 14 ” \mathrm{E}$ & $120^{\circ} 35^{\prime} 50^{\prime \prime} \mathrm{E}$ & $120^{\circ} 35^{\prime} 40^{\prime \prime} \mathrm{E}$ & $120^{\circ} 35^{\prime} 01^{\prime \prime} \mathrm{E}$ & $120^{\circ} 34^{\prime} 40^{\prime \prime} \mathrm{E}$ \\
\hline Landscape Position & Middle backslope & Shoulder & Lower backslope & Summit & Footslope \\
\hline Elevation & $150 \mathrm{~m}$ as 1 & $180 \mathrm{~m}$ asl & $60 \mathrm{~m}$ asl & $220 \mathrm{~m}$ asl & $100 \mathrm{~m}$ asl \\
\hline Slope Class & $30-60 \%$ & $30-60 \%$ & $30-60 \%$ & $1-2 \%$ & $0.5-1 \%$ \\
\hline Gradient & Steep & Steep & Steep & Very gently sloping & Nearly level \\
\hline Slope Form & Convex concave & Convex concave & Concave concave & Convex convex & Straight Concave \\
\hline Orientation & Northeast & Northeast & Northeast & Northeast & Northeast \\
\hline Land use & $\begin{array}{l}\text { Perennial field } \\
\text { cropping }\end{array}$ & $\begin{array}{l}\text { Perennial field } \\
\text { cropping }\end{array}$ & $\begin{array}{l}\text { Perennial field } \\
\text { cropping }\end{array}$ & $\begin{array}{l}\text { Perennial field } \\
\text { cropping }\end{array}$ & $\begin{array}{l}\text { Perennial field } \\
\text { cropping }\end{array}$ \\
\hline Crops or Vegetation & $\begin{array}{l}\text { Coconut trees, shrubs, } \\
\text { grasses and } \\
\text { broadleaves }\end{array}$ & $\begin{array}{l}\text { Banana, Coconut } \\
\text { trees, shrubs, grasses } \\
\text { and broadleaves }\end{array}$ & $\begin{array}{l}\text { Coconut trees, shrubs, } \\
\text { grasses and } \\
\text { broadleaves }\end{array}$ & $\begin{array}{l}\text { Banana, Coconut } \\
\text { trees, shrubs, grasses } \\
\text { and broadleaves }\end{array}$ & $\begin{array}{l}\text { Coconut trees, shrubs, } \\
\text { grasses, broadleaves }\end{array}$ \\
\hline Human Influence & $\begin{array}{l}\text { Vegetation } \\
\text { moderately disturbed }\end{array}$ & $\begin{array}{l}\text { Vegetation } \\
\text { moderately disturbed }\end{array}$ & $\begin{array}{l}\text { Vegetation } \\
\text { moderately disturbed }\end{array}$ & $\begin{array}{l}\text { Vegetation } \\
\text { moderately disturbed }\end{array}$ & $\begin{array}{l}\text { Vegetation } \\
\text { moderately disturbed }\end{array}$ \\
\hline Parent Material & $\begin{array}{l}\text { Andesitic volcanic } \\
\text { rocks }\end{array}$ & $\begin{array}{l}\text { Andesitic volcanic } \\
\text { rocks }\end{array}$ & $\begin{array}{l}\text { Andesitic volcanic } \\
\text { rocks }\end{array}$ & $\begin{array}{l}\text { Andesitic volcanic } \\
\text { rocks }\end{array}$ & $\begin{array}{l}\text { Andesitic volcanic } \\
\text { rocks }\end{array}$ \\
\hline Climate & Wet & Wet & Wet & Wet & Wet \\
\hline Soil Climate & $\begin{array}{l}\text { Isohyperthermic and } \\
\text { Udic }\end{array}$ & $\begin{array}{l}\text { Isohyperthermic and } \\
\text { Udic }\end{array}$ & $\begin{array}{l}\text { Isohyperthermic and } \\
\text { Udic }\end{array}$ & $\begin{array}{l}\text { Isohyperthermic and } \\
\text { Udic }\end{array}$ & $\begin{array}{l}\text { Isohyperthermic and } \\
\text { Udic }\end{array}$ \\
\hline Erosion degree & Moderate & Moderate & Moderate & Slight & Slight \\
\hline Rock outcrops & Common & Common & Common & Very few & Common \\
\hline Drainage & Well-drained & Well-drained & Well-drained & Well-drained & Well-drained \\
\hline
\end{tabular}


All sampling sites were well-drained and showed evidence of moderate (soil profiles 1, 2, 3 and 5) to slight (soil profile 4) erosion, the latter can be explained by its relatively flat topography. The same trends were also observed on rock outcrops wherein all sites had common rating except for soil profile 4 . In general, the sites were located along a catenary landscape subjected to a more or less the same biome, anthropogenic influence, parent material, climate, and time of formation. Topography particularly landscape position appeared to have a dominant influence on the characteristics of the soils in the area.

\section{Soil Morphophysical Properties}

A summary of the morphophysical properties of the soils studied is presented in Tables 2-3. Results showed variations in the morphophysical characteristics of the soils in different landscape positions. Thick solum was observed in soil profiles 4 (summit) and 5 (footslope) which can be explained by deeper weathering due to vertical water movement in the former, and deposition of eroded soil materials in the latter. This finding generally agrees with previous studies that the thickness of solum increases downslope with obvious alluvial stratification at the toeslope due to constant depositional process (Butler 1982, Kachanoski et al 1992, Sommer \& Schlichting 1997, Chen et al 1999).

All soils formed moderate to strong subangular blocky structure in their A horizon except for soil profile 4 which had a strong medium granular structure (Table 2). Moreover, all soils were observed to have friable moist consistency but were slightly hard (soil profile 1) to hard and very hard (soil profiles 2 and 3) and extremely hard (soil profiles 4 and 5) when dry. Moreover, their wet consistency varied from slightly sticky to very sticky when, non-plastic in the surface horizons to very plastic in the subsoil, which could be explained partly by their clay content (Table 3 ). 
Table 2. Soil morphological characteristics of the five soil profiles in the northern volcanic mountain of Leyte

\begin{tabular}{|c|c|c|c|c|c|c|c|c|c|c|c|}
\hline \multirow{2}{*}{$\begin{array}{c}\text { Soil } \\
\text { Profile } \\
\text { No. } \\
\end{array}$} & \multirow[b]{2}{*}{ Horizon } & \multirow{2}{*}{$\begin{array}{l}\text { Depth } \\
\text { (cm) }\end{array}$} & \multirow{2}{*}{$\begin{array}{c}\text { Horizon } \\
\text { boundary }\end{array}$} & \multirow{2}{*}{$\begin{array}{l}\text { Munsell } \\
\text { Color }\end{array}$} & \multirow{2}{*}{ Texture } & \multirow[b]{2}{*}{ Structure } & \multicolumn{3}{|c|}{ Consistence } & \multirow{2}{*}{$\begin{array}{c}\text { Rock } \\
\text { fragments }\end{array}$} & \multirow[b]{2}{*}{ Roots } \\
\hline & & & & & & & Dry & Moist & Wet & & \\
\hline \multirow{4}{*}{1} & $\mathrm{~A}$ & $0-15$ & & $5 Y R 3 / 4$ & SiCL & $\mathrm{MO}, \mathrm{FI}, \mathrm{SB}$ & SHA & FR & SST, SPL & $\mathrm{V}, \mathrm{M}$ & VF, M \\
\hline & $\mathrm{BC}$ & $15-31$ & W & $5 Y R$ 4/4 & SiCL & $\mathrm{MO}, \mathrm{FI}, \mathrm{SA}$ & HA & FR & SST, SPL & $\mathrm{V}, \mathrm{C}$ & $\mathrm{F}, \mathrm{M}$ \\
\hline & $\mathrm{C}_{1}$ & $31-64$ & W & $5 Y R 5 / 4$ & SiL & MA & SHA & FR & ST, SPP & $\mathrm{M}, \mathrm{S}$ & $\mathrm{N}$ \\
\hline & $\mathrm{C}_{2}$ & $>64$ & & $5 Y R 4 / 1$ & $\mathrm{~L}$ & MA & SHA & EFI & SVS, PVP & $\mathrm{M}, \mathrm{S}$ & $\mathrm{N}$ \\
\hline \multirow{5}{*}{2} & A & $0-21$ & & 10YR 3/4 & $\mathrm{C}$ & $\mathrm{MO}, \mathrm{FI}, \mathrm{SB}$ & HA & FR & SST, NPL & $\mathrm{V}, \mathrm{F}$ & VF, M \\
\hline & $\mathrm{AB}$ & $21-43$ & D & $7.5 \mathrm{YR} 4 / 4$ & $\mathrm{C}$ & $\mathrm{MO}, \mathrm{FI}, \mathrm{SB}$ & HA & FR & SST, SPL & $\mathrm{V}, \mathrm{F}$ & $\mathrm{VF}, \mathrm{M}$ \\
\hline & $\mathrm{Bw}_{1}$ & $43-78$ & D & $5 Y R 4 / 6$ & $\mathrm{C}$ & MO, FI, SB & HA & FR & ST, PL & $\mathrm{V}, \mathrm{M}$ & $\mathrm{VF}, \mathrm{M}$ \\
\hline & $\mathrm{Bw}_{2}$ & $78-109$ & D & $5 \mathrm{YR} 4 / 6$ & $\mathrm{C}$ & MO, FI, SB & VHA & FRF & $\mathrm{ST}, \mathrm{PL}$ & $\mathrm{F}, \mathrm{C}$ & $\mathrm{VF}, \mathrm{M}$ \\
\hline & $\mathrm{BC}$ & $109-124$ & $\mathrm{D}$ & $5 \mathrm{YR} 4 / 6$ & $\mathrm{C}$ & $\mathrm{MO}, \mathrm{FI}, \mathrm{SB}$ & VHA & FRF & $\mathrm{ST}, \mathrm{PL}$ & $\mathrm{F}, \mathrm{C}$ & $\mathrm{N}$ \\
\hline \multirow{5}{*}{3} & A & $0-14$ & & 10YR 4/4 & $\mathrm{C}$ & $\mathrm{ST}, \mathrm{ME}, \mathrm{SB}$ & SHA & FR & NST, NPL & $\mathrm{V}, \mathrm{F}$ & $\mathrm{VF}, \mathrm{C}$ \\
\hline & $\mathrm{Bw}_{1}$ & $14-36$ & C & 10YR 3/6 & $\mathrm{SiC}$ & $\mathrm{ST}, \mathrm{ME}, \mathrm{SB}$ & HA & FR & SST, SPL & $\mathrm{N}$ & $\mathrm{VF}, \mathrm{F}$ \\
\hline & $\mathrm{Bw}_{2}$ & $36-64$ & D & 10YR 4/6 & $\mathrm{SiCL}$ & $\mathrm{MO}, \mathrm{MC}, \mathrm{SB}$ & VHA & FR & $\mathrm{ST}, \mathrm{PL}$ & $\mathrm{N}$ & $\mathrm{M}, \mathrm{C}$ \\
\hline & $\mathrm{C}$ & $64-92$ & C & 10YR 6/2 & $\mathrm{SiCL}$ & $\mathrm{MO}, \mathrm{MC}, \mathrm{SB}$ & ND & FI & SST, SPL & $\mathrm{A}, \mathrm{S}$ & $\mathrm{F}, \mathrm{V}$ \\
\hline & $\mathrm{R}$ & $92-130$ & $\mathrm{C}$ & ND & ND & MA & ND & & ND & ND & $\mathrm{N}$ \\
\hline \multirow{4}{*}{4} & A & $0-17$ & & $10 Y R 3 / 3$ & $\mathrm{SiC}$ & $\mathrm{ST}, \mathrm{ME}, \mathrm{GR}$ & VHA & FR & SST, SPL & $\mathrm{V}, \mathrm{M}$ & $\mathrm{F}, \mathrm{C}$ \\
\hline & $\mathrm{Bw}_{1}$ & $17-46$ & W & 10YR 3/6 & $\mathrm{C}$ & $\mathrm{ST}, \mathrm{ME}, \mathrm{SB}$ & VHA & FR & SST, SPL & $\mathrm{N}$ & $\mathrm{M}, \mathrm{F}$ \\
\hline & $\mathrm{Bw}_{2}$ & $46-70$ & $\mathrm{D}$ & $10 \mathrm{YR} 4 / 6$ & $\mathrm{C}$ & $\mathrm{ST}, \mathrm{MC}, \mathrm{SB}$ & EHA & FR & SST, SPL & $\mathrm{N}$ & $\mathrm{M}, \mathrm{V}$ \\
\hline & $\mathrm{Bw}_{3}$ & $70-88$ & C & $10 \mathrm{YR} 4 / 6$ & $\mathrm{C}$ & $\mathrm{MO}, \mathrm{MC}, \mathrm{SB}$ & VHA & FR & ST, PL & $\mathrm{N}$ & $\mathrm{M}, \mathrm{V}$ \\
\hline \multirow{4}{*}{5} & A & $0-15$ & & 10YR 5/5 & $\mathrm{C}$ & MS, ME, SB & HA & FI & SST, SPL & $\mathrm{N}$ & $\mathrm{VF}, \mathrm{C}$ \\
\hline & $\mathrm{Bw}_{1}$ & $15-48$ & $\begin{array}{l}C \\
D\end{array}$ & 10YR 5/4 & $\mathrm{C}$ & $\mathrm{MS}, \mathrm{ME}, \mathrm{SB}$ & EHA & FI & ST, PL & $\mathrm{N}$ & VF, V \\
\hline & $\mathrm{Bw}_{2}$ & $48-85$ & $\begin{array}{l}\mathrm{D} \\
\mathrm{C}\end{array}$ & $10 \mathrm{YR} 5 / 2$ & $\mathrm{C}$ & $\mathrm{MS}, \mathrm{MC}, \mathrm{SB}$ & EHA & VFI & VST, VPL & $\mathrm{N}$ & $\mathrm{VF}, \mathrm{F}$ \\
\hline & $\mathrm{Bw}_{3}$ & $85-115$ & C & 10YR 6/3 & $\mathrm{C}$ & $\mathrm{MS}, \mathrm{MC}, \mathrm{SB}$ & EHA & VFI & VST, VPL & $\mathrm{N}$ & $\mathrm{N}$ \\
\hline
\end{tabular}


Key to morphological abbreviations

\begin{tabular}{|c|c|c|}
\hline Horizon boundary & Consistence & Rock Fragments \\
\hline C Clear $2-5 \mathrm{~cm}$ & Consistence when dry & Abundance \\
\hline D Diffuse $>15 \mathrm{~cm}$ & SHA Slightly hard & N None $0 \%$ \\
\hline W Wavy & HA Hard & V Very few $0-2 \%$ \\
\hline Textural classes & $\begin{array}{l}\text { WHA Very hard } \\
\text { EHA Extremely hard }\end{array}$ & M Medium gravel 6-20 mm \\
\hline SiL silt loam & & C Coarse gravel $20-60 \mathrm{~mm}$ \\
\hline SiCL silty clay loam & Consistence when moist & S Stones $60-200 \mathrm{~mm}$ \\
\hline SiC silty clay & FI Firm & Roots \\
\hline C clay & $\begin{array}{l}\text { VFI Very firm } \\
\text { FRF Friable to firm }\end{array}$ & $\begin{array}{l}\text { Size (diameter) } \\
\text { VF Very fine }<0.5 \mathrm{~mm}\end{array}$ \\
\hline Soil structure & & F Fine $0.5-2 \mathrm{~mm}$ \\
\hline Grade & Consistence when wet & M Medium 2-5 mm \\
\hline MO Moderate & Stickiness & C Coarse $>5 \mathrm{~mm}$ \\
\hline ST Strong & SST Slightly sticky & \\
\hline MS Moderate to strong & $\begin{array}{l}\text { ST Sticky } \\
\text { VST Very sticky }\end{array}$ & $\begin{array}{l}\text { Abundance } \\
\text { N None }\end{array}$ \\
\hline Size & NPL Non plastic & V Very few \\
\hline FI Fine/thin & SPL Slightly plastic & F Few \\
\hline ME Medium & PL Plastic & C Common \\
\hline MC Medium and coarse & $\begin{array}{l}\text { VPL Very plastic } \\
\text { SPP Slightly plastic to plastic }\end{array}$ & M Many \\
\hline $\begin{array}{l}\text { Type } \\
\text { MA Massive } \\
\text { SA Subangular and } \\
\text { angular blocky } \\
\text { SB Subangular blocky } \\
\text { GR Granular }\end{array}$ & PVP Plastic to very plastic & \\
\hline
\end{tabular}

Bulk density values were within the class $1\left(<0.90 \mathrm{~g} / \mathrm{cm}^{3}\right)$ of the FAO Guidelines for Soil Description (Jahn et al 2006). The low bulk density and high clay content of the soils explain their very high water holding capacity (65.53 - 98.85\%). The low bulk density of the soils maybe attributed to the presence of short-range-order minerals commonly found in young volcanic soils particularly Andisols (Shoji et al 1992, Driessen et al 2001) or to the halloysitic clay mineralogy in some old volcanic soils which evolved from Andisols (Asio 1996, Chen et al (1999).

The saturated hydraulic conductivity (Ksat) of the five soils decreased with soil depth. This is expected since soil permeability is affected by the amount of organic matter, rooting, texture, and bulk density (Lal 2000, Bouma et al 2005). The decreasing trend with depth of Ksat could also be attributed to the strong and more stable structure formation in the upper horizon. Ksat values in soil profiles 1, 2, 3, and 4 were generally very high especially in the A horizons allowing large volume of water to permeate down to the profile until it reaches to less permeable layers $(\mathrm{Bt}, \mathrm{C}$ and $\mathrm{R}$ horizons). Soil profile 5 showed a low hydraulic conductivity which could be due to its very high clay content.

Silt/clay ratio has been used by some authors as an indicator of the degree of weathering (Thorn et al 1984, Scalenghe et al 2000). The smaller the ratio, the more weathered is the soil. Results of the study indicated that soil profile 1 (backslope) had considerably higher values than the other soil profiles (Table 3) implying that soil profiles 2, 3, 4, and 5 are relatively older and more weathered than soil profile 1. 
Table 3. Selected physical properties of the five soil profiles in the northern volcanic

\begin{tabular}{|c|c|c|c|c|c|c|c|c|c|}
\hline \multirow{2}{*}{$\begin{array}{c}\text { Soil } \\
\text { Profile } \\
\text { No. }\end{array}$} & \multirow[b]{2}{*}{ Horizon } & \multirow[b]{2}{*}{$\begin{array}{c}\text { BD } \\
\left(\mathrm{g} / \mathrm{cm}^{3}\right)\end{array}$} & \multicolumn{3}{|c|}{ Particle Size Distribution } & \multirow[b]{2}{*}{$\begin{array}{c}\text { WHC } \\
(\%)\end{array}$} & \multirow[b]{2}{*}{$\begin{array}{l}\text { EPAW } \\
(\mathrm{cm} / \mathrm{m})\end{array}$} & \multirow[b]{2}{*}{$\begin{array}{c}\text { Ksat } \\
\text { (cm/day) }\end{array}$} & \multirow[b]{2}{*}{ Silt/Clay } \\
\hline & & & Sand & $\begin{array}{l}\text { Silt } \\
(\%)\end{array}$ & Clay & & & & \\
\hline \multirow{4}{*}{1} & A & 0.77 & 18.45 & 42.28 & 39.27 & 79.18 & 19.0 & 253.27 & 1.08 \\
\hline & $\mathrm{BC}$ & 0.79 & 26.91 & 45.54 & 27.56 & 75.83 & 19.0 & 79.79 & 1.65 \\
\hline & $\mathrm{C}_{1}$ & ND & 35.82 & 48.73 & 15.45 & 75.06 & 20.0 & 64.71 & 3.15 \\
\hline & $\mathrm{C}_{2}$ & ND & 43.58 & 43.81 & 12.61 & 68.04 & 18.0 & 66.67 & 3.47 \\
\hline \multirow{5}{*}{2} & A & 0.89 & 14.20 & 25.40 & 60.40 & 65.82 & 18.0 & 272.15 & 0.42 \\
\hline & $\mathrm{AB}$ & 0.90 & 13.17 & 26.55 & 60.28 & 68.60 & 18.0 & 142.09 & 0.44 \\
\hline & $\mathrm{Bw}_{1}$ & 0.84 & 10.92 & 29.01 & 60.07 & 65.82 & 18.0 & 142.62 & 0.48 \\
\hline & $\mathrm{Bw}_{2}$ & 0.87 & 11.24 & 31.14 & 57.62 & 68.68 & 18.0 & 70.97 & 0.54 \\
\hline & $\mathrm{BC}$ & ND & 11.25 & 34.29 & 54.46 & 68.90 & 18.0 & 70.20 & 0.63 \\
\hline \multirow{5}{*}{3} & A & 0.82 & 13.62 & 38.23 & 48.15 & 71.12 & 18.0 & 508.75 & 0.79 \\
\hline & $\mathrm{Bw}_{1}$ & 0.78 & 12.07 & 41.71 & 46.22 & 78.77 & 18.3 & 545.53 & 0.90 \\
\hline & $\mathrm{Bw}_{2}$ & 0.86 & 13.56 & 48.16 & 38.28 & 77.77 & 19.0 & 166.16 & 1.26 \\
\hline & $\mathrm{C}$ & ND & 19.80 & 46.20 & 34.00 & 78.13 & 19.0 & 49.17 & 1.36 \\
\hline & $\mathrm{R}$ & ND & ND & ND & ND & ND & ND & ND & ND \\
\hline \multirow{4}{*}{4} & A & 0.91 & 13.32 & 42.35 & 44.33 & 65.53 & 18.3 & 220.11 & 0.96 \\
\hline & $\mathrm{Bw}_{1}$ & 0.83 & 10.22 & 36.13 & 53.65 & 68.86 & 18.0 & 351.62 & 0.67 \\
\hline & $\mathrm{Bw}_{2}$ & 0.87 & 8.66 & 36.27 & 55.07 & 72.99 & 18.0 & 107.76 & 0.66 \\
\hline & $\mathrm{Bw}_{3}$ & 0.89 & 9.95 & 32.74 & 57.31 & 80.10 & 18.0 & 23.35 & 0.57 \\
\hline \multirow{4}{*}{5} & A & 0.75 & 2.81 & 37.80 & 59.40 & 98.85 & 18.0 & 68.74 & 0.64 \\
\hline & $\mathrm{Bw}_{1}$ & 0.72 & 2.36 & 39.39 & 58.24 & 96.81 & 18.0 & 0.51 & 0.68 \\
\hline & $\mathrm{Bw}_{2}$ & 0.80 & 1.40 & 40.20 & 58.40 & 97.32 & 18.0 & 0.16 & 0.69 \\
\hline & $\mathrm{Bw}_{3}$ & 0.81 & ND & ND & ND & ND & 18.0 & 0.55 & ND \\
\hline
\end{tabular}

ND-No data, BD-bulk density WHC-water holding capacity, EPAW-estimated plant available water, Ksat-saturated hydraulic capacity

\section{Soil Chemical Properties}

Table 4 presents the results of chemical analyses. All the soils studied had acidic condition as indicated by their $\mathrm{pH}\left(\mathrm{H}_{2} \mathrm{O}\right)$ values ranging from 4.30 to 5.79. According to van Wambeke (1992) acidity is a common feature of humid tropical volcanic soils because of rapid leaching and the advancement of weathering and there are not enough bases present to neutralize organic acids. Moreover, $\mathrm{pH}(\mathrm{NaF})$ values were $>9.0$ in all soils suggesting the occurrence of allophanic minerals and/or organoaluminum complexes (Fieldes \& Perrot 1966, Nieuwenhuyse et al 2000, Alves \& Lavorenti 2004). Parfitt (1990) reported that under acidic conditions, particularly at higher altitudes or at lower temperatures, the Al-humus complex may predominate in horizons with a $\mathrm{pH}<4.8$. The high $\mathrm{pH}(\mathrm{NaF})$ value also reflects the abundance of active $\mathrm{Al}$ in the soils (Chen et al. 1999), presence of allophane and imogolite which are poorly crystalline materials and have variable charge (Parfitt \& Kimble 1989, Wada 1989), and high P-fixation capacities in the soils (Gilkes \& Hughes 1994). 
Organic $\mathrm{C}$ was highest in the surface horizon and decreased with depth in all soils which is due to the accumulation of plant litter from the vegetation cover. Soil profile 4 (summit) had slightly higher organic $C$ in the surface horizon compared with the other soils which is indicative of a more stable geomorphic position.

The total $\mathrm{N}$ content of the soils followed the trend observed for organic $\mathrm{C}$ showing only slight variation across landscape positions. Furthermore, values obtained for available P were all below $10 \mathrm{mg} / \mathrm{kg}$ which could be attributed to their high $P$ fixing capacity which is common in acidic young volcanic soils and old acidic soils due to the precipitation of $\mathrm{P}$ by $\mathrm{Al}$ and $\mathrm{Fe}$. Soil profile 1 showed a slight increase in available $\mathrm{P}$ with soil depth. In contrast, the available $\mathrm{P}$ contents of soil profiles 2,3 and 4 considerably decreased with soil depth, while soil profile 5 had irregular trend which could be attributed to the periodic deposition of soil materials from the upper slopes.

CEC values ranged from 21.94-86.12 cmol/ $\mathrm{kg}$ and are considered moderate to high (GUSTR 2005, IUSS Working Group on WRB 2006) and could be due to the high clay content of the soils. All soils generally had low exchangeable $\mathrm{K}(<0.4 \mathrm{cmol} / \mathrm{kg})$. Similarly, exchangeable Ca contents were less than $5 \mathrm{cmol} / \mathrm{kg}$ in all soil profiles except for soil profile 5 which had 5-10 cmol/kg). Exchangeable Mg was high in soil profiles 1 and 5 but medium to low in soil profiles 2, 3 and 4 .

CEC/Clay ratios were also calculated to give an idea of the type and activity of clay that dominated in the soils. CEC/Clay ratio in all soils ranged from $25-237 \mathrm{cmol} / \mathrm{kg}$ clay (Table 4), which indicates the presence of relatively active clays (IUSS Working Group on WRB 2006).

\section{Soil Classification}

The five soil profiles in the study area were in the early stage of development as indicated by their profile characteristics. They all belonged to Inceptisols and since they all had low base saturation they were classified as Dystrudepts. Moreover, they showed some properties of Andisols particularly their low bulk density values and $\mathrm{pH}$ in $\mathrm{NaF}$ of more than 9.5. According to Soil Taxonomy (Soil Survey Staff 2014), Dystrudepts that have a fine-earth fraction with both a bulk density of $1.0 \mathrm{~g} / \mathrm{cm} 3$ or less and Al plus $1 / 2$ Fe percentages (by ammonium oxalate) totaling more than 1.0 are classified as Andic Dystrudepts. In the World Reference Base (FAO 2006), the soils maybe classified as Andic Cambisols. It should be mentioned that this classification is tentative due to the absence of data on oxalate-extractable $\mathrm{Al}$ and $\mathrm{Fe}$, phosphate retention, and clay minerals. Some of the soils may in fact qualify as Andisols (Andosols) and thus they need more detailed pedological studies. 
Table 4. Selected chemical properties of the five soil profiles in the northern volcanic mountain in Leyte

\begin{tabular}{|c|c|c|c|c|c|c|c|c|c|c|c|c|c|c|}
\hline \multirow{2}{*}{$\begin{array}{c}\text { Soil Profile } \\
\text { No. }\end{array}$} & \multirow{2}{*}{ Horizon } & \multicolumn{2}{|c|}{ Soil pH } & \multirow{2}{*}{$\begin{array}{c}\text { Organic C } \\
(\%)\end{array}$} & \multirow{2}{*}{$\begin{array}{c}\text { Total N } \\
(\%)\end{array}$} & \multirow{2}{*}{$\begin{array}{l}\text { Available } \\
\text { P (ppm) }\end{array}$} & \multicolumn{4}{|c|}{$\begin{array}{c}\text { Exchangeable Bases } \\
(\mathrm{cmol} / \mathrm{kg})\end{array}$} & \multirow{2}{*}{$\begin{array}{c}\mathbf{C E C} \\
(\mathrm{cmol} / \mathrm{kg})\end{array}$} & \multicolumn{2}{|c|}{$\begin{array}{c}\text { Saturation } \\
(\%)\end{array}$} & \multirow{2}{*}{$\begin{array}{l}\text { CEC/Clay } \\
(\mathrm{cmol} / \mathrm{kg})\end{array}$} \\
\hline & & $\mathrm{H}_{2} \mathrm{O}$ & $\mathrm{NaF}$ & & & & $\mathbf{K}$ & $\mathrm{Ca}$ & $\mathrm{Mg}$ & $\mathrm{Na}$ & & Base & Ca & \\
\hline \multirow{4}{*}{1} & A & 5.79 & 9.48 & 1.40 & 0.21 & 8.22 & 0.60 & 3.70 & 4.33 & 0.16 & 65.92 & 13.33 & 5.61 & 168 \\
\hline & $\mathrm{BC}$ & 5.40 & 10.06 & 0.32 & 0.10 & ND & 0.42 & 2.51 & 2.61 & 0.14 & 65.37 & 8.69 & 3.84 & 237 \\
\hline & $\mathrm{C}_{1}$ & 5.29 & 10.29 & 0.06 & 0.01 & ND & 0.37 & 3.25 & 2.54 & 0.13 & 44.00 & 14.28 & 7.38 & ND \\
\hline & $\mathrm{C}_{2}$ & 5.37 & 10.43 & 0.02 & 0.03 & ND & 0.34 & 4.01 & 2.67 & 0.13 & 58.45 & 12.23 & 6.86 & ND \\
\hline \multirow{5}{*}{2} & A & 4.60 & 10.20 & 1.88 & 0.22 & 2.32 & 0.21 & 1.50 & 0.64 & 0.13 & 22.52 & 11.03 & 6.67 & 37 \\
\hline & $\mathrm{AB}$ & 4.61 & 10.36 & 0.81 & 0.10 & 1.21 & 0.12 & 1.19 & 0.24 & 0.15 & 22.55 & 7.53 & 5.25 & 37 \\
\hline & $\mathrm{Bw}_{1}$ & 4.62 & 10.51 & 0.56 & 0.06 & 1.21 & 0.08 & 1.87 & 0.54 & 0.11 & 21.94 & 11.84 & 8.50 & 37 \\
\hline & $\mathrm{Bw}_{2}$ & 4.67 & 10.75 & 0.48 & 0.06 & 0.61 & 0.13 & 2.00 & 0.55 & 0.22 & 23.93 & 12.10 & 8.34 & 42 \\
\hline & $\mathrm{BC}$ & 4.70 & 10.83 & 0.44 & 0.04 & 0.70 & 0.10 & 1.81 & 0.53 & 0.13 & 29.41 & 8.76 & 6.16 & 54 \\
\hline \multirow{5}{*}{3} & $\mathrm{~A}$ & 4.42 & 10.34 & 1.86 & 0.20 & 8.66 & 0.39 & 2.40 & 1.51 & 0.22 & 35.06 & 12.88 & 6.84 & 73 \\
\hline & $\mathrm{Bw}_{1}$ & 4.40 & 10.47 & 0.06 & 0.11 & 1.08 & 0.12 & 2.20 & 1.21 & 0.21 & 39.16 & 9.55 & 5.62 & 85 \\
\hline & $\mathrm{Bw}_{2}$ & 4.48 & 10.86 & 0.15 & 0.04 & 4.28 & 0.06 & 2.00 & 1.10 & 0.14 & 86.12 & 3.82 & 2.32 & 25 \\
\hline & $\mathrm{C}$ & 4.48 & 11.06 & 0.28 & 0.02 & 0.28 & 0.05 & 2.01 & 1.23 & 0.15 & 46.39 & 7.42 & 4.32 & 36 \\
\hline & $\mathrm{R}$ & 4.30 & 11.04 & 0.19 & 0.03 & 1.07 & 0.01 & 1.88 & 1.05 & 0.13 & 38.07 & 8.08 & 4.94 & ND \\
\hline \multirow{4}{*}{4} & A & 4.51 & 10.34 & 1.84 & 0.18 & 1.82 & 0.30 & 2.78 & 1.16 & 0.04 & 37.15 & 11.54 & 7.49 & 84 \\
\hline & $\mathrm{Bw}_{1}$ & 4.48 & 10.75 & 1.21 & 0.12 & 1.24 & 0.15 & 2.80 & 0.88 & 0.05 & 38.45 & 10.10 & 7.29 & 72 \\
\hline & $\mathrm{Bw}_{2}$ & 4.70 & 10.65 & 0.63 & 0.08 & 0.10 & 0.08 & 2.37 & 0.79 & 0.07 & 40.17 & 8.24 & 5.89 & 73 \\
\hline & $\mathrm{Bw}_{3}$ & 4.64 & 10.86 & 0.63 & 0.11 & 0.19 & 0.08 & 2.32 & 0.71 & 0.04 & 40.66 & 7.76 & 5.71 & 71 \\
\hline \multirow{4}{*}{5} & A & 4.74 & 10.47 & 1.39 & 0.16 & 5.45 & 0.14 & 7.31 & 2.23 & 0.07 & 69.75 & 13.98 & 10.48 & 117 \\
\hline & $\mathrm{Bw}_{1}$ & 4.74 & 10.65 & 0.68 & 0.09 & 2.61 & 0.12 & 8.20 & 2.30 & 0.09 & 48.06 & 22.27 & 17.06 & 83 \\
\hline & $\mathrm{Bw}_{2}$ & 5.17 & 10.48 & 0.28 & 0.06 & 10.60 & 0.13 & 9.82 & 2.45 & 0.07 & 57.01 & 21.87 & 17.23 & 98 \\
\hline & $\mathrm{Bw}_{3}$ & 5.06 & ND & ND & ND & ND & ND & ND & ND & ND & ND & ND & ND & ND \\
\hline
\end{tabular}


Soil development in relation to landscape positions

Hall (1983) suggested that the movement of water is the primary cause of material movement on slopes on most landscapes. He considered that water movement and distribution on slopes is the principal reason for differences in soils on the landscape. A number of past researches have attempted to relate processes and soils to landscape position (Hall 1983). The use of the five landscape positions proposed by Ruhe (1960) which include summit, shoulder, backslope, footslope and toeslope, has contributed to our understanding of soil-landscape relationships. Pedological and hydrological processes vital for soil development often occur at varying rates along these positions (Ruhe 1960, Hall 1983) resulting in the variability of soils in the landscape. Moreover, Daniels and Hammer (1992) mentioned that much of the soil variability on a landscape results from material variability.

Soil profile 1 was located on the middle backslope at a slope ranging from $30-60 \%$. The soil had a thin solum of $31 \mathrm{~cm}$ and showed poor soil development. This is largely the effect of its landscape position. Hall (1983 $\& 2003$ ) reported that transportation of materials is the dominant process on backslope positions which is also a relatively unstable position.

Soil profile 2 was situated on the shoulder position at a slope of 30$60 \%$. The soil had a thick solum of more than $100 \mathrm{~cm}$ and an average clay content of close to $60 \%$ indicating more advanced stage of development than soil profile 1 and 3. According to Hall (1983 \& 2003) surface runoff is maximized in this landscape position resulting in a highly erosional and unstable surface. Lateral subsurface water movement is also an important process in this position.

Soil profile 3 developed on the lower backslope position at a slope of $30-60 \%$. It had a solum thickness of $64 \mathrm{~cm}$ and showed a slightly more developed profile than soil profile 1. As already mentioned above, transport of material, both at the surface and subsurface, is the dominant process on this position. In terms of silt/clay ratio, soil profiles 1 and 3 have high values compared to the other soil profiles.

Soil profile 4 was formed on the summit which was an almost flat geomorphic surface having a slope of $1-2 \%$. The soil had a thick solum of close to $90 \mathrm{~cm}$ and a clay content ranging from 44 to $57 \%$. The soil had a slightly more developed profile compared to the three previous soils mentioned above. The summit position is considered to be the most stable landscape position. Water movement in the soil is largely vertical resulting in thick solum (Hall 1983).

Soil profile 5 was located on the footslope position having a slope of about $1 \%$. It had the thickest solum of $115 \mathrm{~cm}$ as a result of its landscape position. According to Hall (1983), concavity is characteristic of this landscape position. The position is constructional and unstable due to the deposition of materials from the upper slope. Soils in footslope positions 
are commonly very heterogeneous due to the mass movement, irregular seepage and non-uniform deposition.

\section{Fertility and Crop Production Suitability of the Soils}

Results showed that the soils in the different landscape positions had varying fertility characteristics and crop production suitability (Table 5). Soil profiles 2 to 5 had deep solum while soil profile 1 had a thin solum which could limit crop rooting and anchorage. In the addition, all soils had low bulk density values which favor crop production. The silty clayey texture in soils of soil profiles 1,3 and 4 together with their friable subangular blocky structure may enhance diffusion of gases and movement water in the soil. However, the very high clay content in soils 2 and 5 which had subangular blocky structure that turns hard upon drying is a limitation during dry periods. Additionally, the sticky and slightly plastic consistency of the soils could pose a problem in farm operations. The very high capacity of the soils to permit water movement (Ksat) in surface horizons of all soil profiles could be a hindrance in irrigation management. On the other hand, the low conductivity in the subsoil of soil profile 5 could cause water-logging during rainy periods.

Table 5. Fertility and crop production suitability of soils in the northern volcanic mountain of Leyte

\begin{tabular}{|c|c|c|c|c|c|c|}
\hline \multirow{2}{*}{ Soil Properties } & \multirow{2}{*}{$\begin{array}{c}\text { Optimum } \\
\text { value/condition }\end{array}$} & \multicolumn{5}{|c|}{ Soil Profiles } \\
\hline & & 1 & 2 & 3 & 4 & 5 \\
\hline Depth $(\mathrm{cm})^{1}$ & $>50$ & - & +++ & +++ & +++ & +++ \\
\hline Texture $^{2}$ & Medium & ++ & --- & + & + & --- \\
\hline Bulk density $\left(\mathrm{g} / \mathrm{cm}^{3}\right)^{3}$ & $<1.45$ & +++ & +++ & +++ & +++ & +++ \\
\hline Consistence $^{4}$ & FR, NP, NS & + & + & + & + & - \\
\hline $\mathrm{K}$ sat $(\mathrm{cm} / \mathrm{day})^{5}$ & $10-40$ & -- & -- & - & -- & --- \\
\hline $\mathrm{pH}(\text { water })^{4}$ & $5.5-7.0$ & + & --- & --- & --- & -- \\
\hline OM $(\%)^{6}$ & $>3.0$ & --- & --- & --- & --- & --- \\
\hline Total N $(\%)^{6}$ & $>0.20$ & + & + & + & - & --- \\
\hline Avail. P (mg/kg) ${ }^{6}$ & $>8-15$ & + & --- & + & --- & --- \\
\hline Exch. K $(\mathrm{cmol} / \mathrm{kg})^{6}$ & $>0.20$ & ++ & + & + & + & --- \\
\hline Exch. Ca $(\mathrm{cmol} / \mathrm{kg})^{6}$ & $>0.40$ & +++ & +++ & +++ & +++ & +++ \\
\hline Exch. $\mathrm{Mg}(\mathrm{cmol} / \mathrm{kg})^{7}$ & $>0.50$ & +++ & ++ & +++ & +++ & +++ \\
\hline $\mathrm{CEC}(\mathrm{cmol} / \mathrm{kg})^{8}$ & $>12-40$ & +++ & ++ & ++ & ++ & +++ \\
\hline $\begin{array}{l}\text { Plus sign (+) indicates favorable } \\
\text { moderate constraint, (---) major } \\
\text { Depth considers the solum thick } \\
\text { Dept } \\
{ }^{1} \text { Based on Schlichting et al. (1995 } \\
{ }^{2} \text { Based on Landon (1991). Clay te } \\
{ }^{3} \text { Based on Arshad et al. (1996). } \\
{ }^{4} \text { Based on Asioet al. (2006). } \\
{ }^{5} \text { Based on Jahn et al. (2006). } \\
{ }^{6} \text { Based on Landon (1991). } \\
{ }^{7} \text { Based on Haby etal. (1990). } \\
{ }^{8} \text { Based on Mengel (1993). }\end{array}$ & $\begin{array}{l}++ \text { moderately favorabl } \\
\text { onstraint; FR, friable; NP, } n \\
\text { ess. } \\
\text { ture with granular structu }\end{array}$ & $\begin{array}{l}++ \text { highl } \\
\text { lastic, NS }\end{array}$ & $\begin{array}{l}\text { rable; m } \\
\text { ticky. }\end{array}$ & ign (-) so & perty is & straint, \\
\hline
\end{tabular}


Soil $\mathrm{pH}$ values revealed the acidic condition of the soils. Acid soil condition could readily solubilize $\mathrm{Al}$ and $\mathrm{Mn}$ complexes to release $\mathrm{Al}$ and $\mathrm{Mn}$ ions, which accumulates and become toxic to plants (Shi \& Zhu 2008) and inhibiting microbial activity (Craswell \& Pushparajah 1989). The low amount of available $\mathrm{P}$ in soil profiles 2,4 , and 5 may limit soil productivity and crop production, although soil profiles 1 and 3 pass the criterion for optimum P levels. Since P is one of the macronutrients and is needed by crops in large quantity, it could still be considered as limiting factor for perennial crop production. Soil profiles 4 and 5 showed limited $\mathrm{N}$ levels while soil profiles 1,2 and 3 were found sufficient.

Data on exchangeable bases showed favorable levels but become a constraint with respect to their concentration ratio (Tisdale et al 1985). Additionally, soil profile 5 showed very low $\mathrm{K}$ contents which could be a constraint to crops production. The soils had moderate to high capacity to exchange cations suggesting that the soils had the capacity to hold more ionic nutrients.

\section{CONCLUSIONS}

The study demonstrated that the degree of soil development and soil morphophysical and chemical properties varied with landscape position in the volcanic mountain studied. The soil in the most stable position (summit) showed thicker solum and slightly more developed soil profile than the soils in other positions. On the other hand, soils in the unstable position (backslope) generally had soils with thinner solum. All the five soils also revealed the influence of the andesitic volcanic parent material on the soils. They all showed some properties typical of Andisols such as low bulk density and high $\mathrm{pH}$ in $\mathrm{NaF}$ although they were classified as Andic Dystrudept. The soils all possessed physical and chemical constraints for crop production. The position of the soil in the landscape appeared to influence the kind of constraint possessed by the soils.

\section{REFERENCES}

ALVES, M. E. and A. LAVORENTI. 2004. Clay mineralogy effects on sodium fluoride $\mathrm{pH}$ of non-allophanic tropical soils. Australian Journal of Soil Research 42: 865-874.

AMOOZEGAR, A. and A.W. WARRICK. 1986. Hydraulic conductivity of saturated soils: Field Methods. pp. 735-768. In: Methods of Soil Analysis. Part 1. Physical and Mineralogical Methods (Ed. A. Klute). SSSA Book Series: 5 (formerly Agronomy Monograph 9). Madison, Wisconsin, USA.

ARSHAD, M. A., B. LOWERY, and B. GROSSMAN. 1996. Physical tests for monitoring soil quality. In: J.W. Doran and A. J. Jones (eds.). Methods for Assessing Soil Quality. SSSA Special Publ. No. 49, Madison, WI, pp. 123-141. 
ASIO, V. B. 1996. Characteristics, Weathering, Formation and Degradation of Soils from Volcanic Rocks in Leyte, Philippines. Hohenheimer Bodenkundliche Hefte, vol. 33, Stuttgart, Germany.

ASIO V.B. and R. JAHN. 2007. Weathering of basaltic rock and clay mineral formation in Leyte, Philippines. Philippine Agricultural Scientist 90 (3): 204-212.

ASIO, V. B., R. JAHN, K. STAHR and J. MARGRAF. 1998. Soils of the Tropical Forests of Leyte, Philippines, II. In Schulte, A. \& D. Ruhiyat (eds.): Soils of Tropical Forest Ecosystems. Springer-Verlag, Berlin.

ASIO, V. B., C. C. CABUÑOS JR and Z. S. CHEN. 2006. Morphology, physiochemical characteristics, and fertility of soils from Quaternary limestone in Leyte, Philippines. Soil Science 171 (8):648-661.

ASIO, V.B., S.B. LINA, D.S. MARANGUIT, A.B. BOLLEDO, R.J.T. DOGUILES, C.M.O. QUIÑONES, J.R. SABIJON AND K.L.B. DEMAIN. 2014. Characteristics of soils in the marginal uplands of Inopacan, Leyte. Annals of Tropical Research 36 (Supplement): 1-15.

AURELIO, M. A. 1992. Tectonique du segment central de al faille Philippine (etude structurale, cin`ematique et evolution geodynamique), These de Doctorat, Universite Pierre et Marie Curie, Paris, France.

BARRERA, A., I. ARISTORENAS and J. TINGZON. 1954. Soil Survey of Leyte Province, Philippines. Bureau of Print, Manila.

BLAKE, G.R. and K.H. HARTGE, 1986, Bulk Density. In: Methods of Soil Analysis, Part I. Physical and Mineralogical Methods (A. Klute, editor). Agronomy Monograph no. 9 (2nd edition), pp.363-375.

BOUMA J., R.B. BROWN and P.S.C. RAO. 2005. Movement of Water: Basics of Soil-Water Relationships - Part III. University of Florida, Institute of Food and Agricultural Sciences (UF/IFAS). Florida, USA.

BUTLER, B. E. 1982. A new system for soil studies. Journal of Soil Science, 33:581-595.

CHEN, Z. S., V. B. ASIO, and D. F. Yi. 1999. Characteristics and genesis of volcanic soils along a toposequence under a subtropical climate in Taiwan. Soil Science 164:510-525.

CRASWELL, E.T. and E. PUSHPARAJAH (eds). 1989. Management of Acid Soils in the Tropics of Asia. Australian Centre for International Agricultural Research. G.P.O. Box 15511, Canberra.

DANIELS R.B. and R.D. HAMMER. 1992. Soil Geomorphology. John Wiley and Sons, Inc., New York.

DRIESSEN P., J. DECKERS, O. SPAARGAREN and F. NACHTERGAELE. 2001. Lecture Notes on the Major Soils of the World. FAO, Rome.

ELLER E. and V. B. Asio. 1991. The flash flood tragedy of Ormoc: a short analysis from a physio-geographical view. Giessener Beitraege Zur Entwicklungsforshung, Justus Liebig University. Giessen, Band 19:115-125

FIELDES, M. and K.W. PERROTT. 1966. The nature of allophane in soils: Part 3. Rapid field and laboratory test for allophone. New Zealand Jour. of Sci. 9:623-629. 
FORMAN, R. T. T. 1995. Land Mosaics. The Ecology of Landscapes and Regions. Cambridge Univ. Press, Cambridge.

FOOD AND AGRICULTURE ORGANIZATION (FAO). 2006. World Reference Base for Soil Resources. World Soil Resources Report 103, FAO, Rome.

GILKES, R. J. and J.C. HUGHES. 1994. Sodium fluoride $\mathrm{pH}$ of south-western Australian soils as indicator of P-sorption. Australian Journal of Soil Research 32:755-766.

GUIDE TO USE OF SOIL TEST RESULTS (GUSTR). 2005. Explanation of Exchangeable Cation Analysis and Interpretation. Department Natural Resources. New South Wales.

HABY, V.A., M.P. RUSELLE and E.O. SKOGLEY. 1990. Testing soils for potassium, calcium, and magnesium. In: Westerman, R.L. (editor). Soil Testing and Plant Analysis, 3rd edn. SSSA Book Ser. 3. SSSA, Madison Wisconsin, pp. 181-227.

HALL, G. F. 1983. Pedology and Geomorphology. 15 pp. In: L.P. Wilding, N.E. Smeck, and G.F. Hall (editors). Pedogenesis and Soil Taxonomy. I. Concepts and Interactions. Elsevier, Amsterdam.

HALL, G. 2003. Landscape. In: Encyclopedia of Soil Science. Vol. 2. Taylor and Francis, New York, pp: 996-999.

INTERNATIONAL SOIL REFERENCE and INFORMATION CENTER (ISRIC). 1995. Procedures for Soil Analysis (L.P. Van Reuwijk, editor) Wageningen, The Netherlands.

IUSS WORKING GROUP WRB. 2006. World Reference Base for Soil Resources. World Soil Resources Report No. 103. FAO, Rome.

JACKSON, M. L. 1958. Soil Chemical Analysis. Prentice Hall Inc., Englewood Cliffs, New Jersey, USA.

JAHN R and V.B. ASIO. 2006. Climate, Geology and Soils of the Tropics with Special Reference to Southeast Asia and Leyte (Philippines). In: Proceedings of the 11th International Seminar-Workshop on Tropical Ecology, 21-25 August 2006, Visayas State University, Baybay City, Leyte, pp: 23-42

JAHN R., H.P. BLUME, V.B. ASIO, O. SPAARGAREN, and P. SCHAD. 2006. Guidelines for Soil Description. FAO, Rome, Italy.

JARA, A. A., A. VIOLANTE, M. PIGNA and M.D. MORA. 2006. Mutual interactions of sulfate, oxalate, citrate, and phosphate on synthetic and natural allophanes. Soil Science Society of American Journal 70:337-346.

KACHANOSKI, R. G., M.H. MILLER, D.A. LOBB, E.G. GREGORICH and R.D. PROTZ. 1992. Management of farm field variability I. Quantification of soil loss in complex topography. II. Soil erosion processes on shoulder slope landscape positions. Final Report No. 38. Technology Evaluation and Development Sub-Program, Soil and Water Environmental Enhancement Program. Agriculture Canada, Harrow, Ontario, Canada.

LAL, R. 2000. Mulching effects on soil physical quality of an Alfisol in Western Nigeria. Land Degradation and Development. Land Degradation and Development 2: 383 - 392. 
LANDON, J. R. (editor) 1991. Booker Tropical Soil Manual. (2nd ed). Longman Technical and Scientific, Harlow, England.

MARANGUIT, D.S. and V.B. ASIO. 2013. Morpho-physical and chemical characteristics of mountain soils in Central Leyte. Annals of Tropical Research 35(1):35-60

MENGEL, D. B. 1993. Fundamentals of Soil Cation Exchange Capacity (CEC). Purdue University Cooperative Extension Service West Lafayette, Indiana, USA.

MOHR E.C.J., F.A. VAN BAREN and J. SCHUYLENBORGH, 1972. Tropical Soils. A comprehensive study of their genesis. ( $3^{\text {rd }}$ edition). Mouton, The Hague.

MURPHY, J. and J. P. RILEY. 1962. A modified single solution method for the determination of phosphorous in natural water. Anal. Chem. Acta 27:31-36.

NAVARRETE, I.A., K. TSUTSUKI, R. KONDO and V.B. ASIO. 2008. Genesis of soils across a late Quaternary volcanic landscape in the humid tropical island of Leyte, Philippines. Australian Journal of Soil Research 46: 403-414.

NAVARRETE, I. A., K. TSUTSUKI, V. B. ASIO, and R. KONDO. 2009. Characteristics and formation of rain forest soils derived from late Quaternary basaltic rocks in Leyte, Philippines. Environmental Geology 58: 1257-1268.

NIEUWENHUYSE, A., P.S.J. VERBURG and JONGMANS, A. G. 2000. Mineralogy of a soil chronosequence on andesitic lava in humid tropical Costa Rica. Geoderma 98: 61-82.

OVALLES F. A. and M.E. COLLINS. 1986. Soil-landscape relationships and soil variability in north central Florida. Soil Science Society of American Journal 50: 401-408.

PARFITT, R.L. 1990. Allophane in New Zealand- a review. Australian Journal of Soil Research 28: 343-360.

PARFITT, R.L. and J.M. KIMBLE. 1989. Conditions for formation of allophane in soils. Soil Science Society of American Journal 53:971977.

PCARR. 1980. Standard Method of Analysis for Soil, Plant Tissue, Water and Fertilizer. PCARR, Los Baños, Laguna.

PIAMONTE M.K.B., V.B. ASIO and S.B. LINA. 2014. Morpho-physical and chemical characteristics of strongly weathered soils in Silago, Southern Leyte, Philippines. Annals of Tropical Research 36: 115-147.

PODWOJEWSKI, P., J. POULENARD, M.L. NGUYET, A. DE ROUW and N.V. THIET. 2011. Climate and vegetation determine soil organic matter status in an alpine inner-tropical soil catena in the Fan Si Pan Mountain, Vietnam. Catena 87 (2): 226-239.

POUDEL, D.D., and L.T. WEST 1999. Soil development and fertility characteristics of a volcanic slope in Mindanao, the Philippines. Soil Science Society of American Journal 63:1258-1273. 
RUHE R.V. 1960. Elements of the soil landscape. Transactions of the $7^{\text {th }}$ International Congress of Soil Science, Madison, 4:165-170.

RUHE R. V. 1975. Geomorphology. Houghton Miffin, Boston, Maryland.

SCALENGHE, R., E. ZANINI and D.R. NIELSEN. 2000. Modeling soil development in a post-incisive chronosequence. Soil Science 165(6):455-462

SCHLICHING. E. 1982. Pedology research: soil genesis. Trans. 12th Int. Congr. Soil Science, New Delhi, India, 5: 267-276.

SCHLICHTING E., H.P. BLUME, and K. STAHR. 1995. Bodenkundliches Practikum. (2nd edn). Blackwell, Berlin, Germany.

SHI, Q. and Z. ZHU. 2008. Effects of exogenous salicylic acid on manganese toxicity, element contents and antioxidative system in cucumber. Environmental and Experimental Botany 63:317-326.

SHOJI, S., M. NANZYO and R. DAHLGREN. 1993. Volcanic Ash Soils: Genesis, Properties and Utilization. Development in Soil Science 21, Elsevier, Amsterdam.

SOIL INFORMATION SYSTEMS UNIT. 2002. Soil Landscape Reconnaissance Mapping - Brigalow Belt South Stage 2, Department of Land and Water Conservation, Sydney, NSW.

SOIL SURVEY STAFF. 2014. Keys to Soil Taxonomy (12 ${ }^{\text {th }}$ edition). United States Department of Agriculture Natural Resources Conservation Service, Washington, D.C.

SOMMER, M. and E. SCHLICHTING. 1997. Archetypes of catenas in respect to matter-a concept for structuring and grouping catenas. Geoderma 76:1-33.

STAHR, K. 1990. Stoffverlagerungen in Böden und Landschaften. In: K. Stahr, H.-P. Blume, and R. Jahn (editors), "Ernst Sch1ichting Memorial Workshop". Ulmer Verlag, Stuttgart, Germany, pp: 58-68.

THORN, E. C., J.C. DIXON and R.G. DARMODY. 1984. Chemical weathering process on the Vantage Peak Nunaak, Juneau Icefield, Southern Alaska. Physical Geography, 5 (2): 111-131.

TISDALE, S. L., W.L. NELSON and J. D. BEATON. 1985. Soil fertility and Fertilizers. ( $4^{\text {th }}$ edition). Mac Millan Publishing Company, New York.

TSUI, C. C., Z. S. CHEN and C. F. HSIEH. 2004. Relationships between soil properties and slope position in a lowland rain forest of southern Taiwan. Geoderma 123:131-142.

TURNER, M. G. and R.H. GARDNER. 1991. Quantitative Methods in Landscape Ecology: The Analysis and Interpretation of Landscape Heterogeneity. Springer-Verlag, New York.

USDA-NRCS. 1996. Soil survey laboratory methods manual. Soil Survey Investigation Report No. 42, Version 3.0. USDA-Natural Resources Conservation Service, National Soil Survey Center, Lincoln, NE. 
VAN WAMBEKE, A. 1992. Soils of the Tropics: Properties and Appraisal. McGraw-Hill, New York.

VERSTAPPEN, H. T. H. 1997. The effect of climatic change on Southeast Asian Geomorphology. Journal of Quaternary Science 12: 413-418.

WADA, K. 1989. Allophane and imogolite. In: Minerals in Soil Environments (J.B. Dixon and S.B. Weed, editors). 2nd ed. SSSA Book Ser. 1. SSSA. Madison. WI.pp. 1051-1087

WESTERMAN, R. L. (editor). 1990. Soil Testing and Plant Analysis. (3rd edition). Soil Sci. Soc. Am., Madison, WI.

ZIKELI S., V.B. ASIO and R. JAHN. 2000. Nutrient status of soils in the rain forest of Mt. Pangasugan, Leyte, Philippines. Annals of Tropical Research 22: 78-88. 